\title{
THE EFFECTIVENESS OF WRITTEN CORRECTIVE FEEDBACK IN TEACHING WRITING CAUSE EFFECT AT THE ELEVENTH GRADE OF SMA NEGERI 1 GROGOL KEDIRI
}

\author{
Ratna Dewi Pamungkas, Agus Amroni
}

\begin{abstract}
This article aims to know the Effectiveness of Written Corrective Feedback in Teaching Writing Cause Effect at the Eleventh Grade of SMAN 1 Grogol Kediri. This research was quantitative experimental design, more specifically uses true experimental by posttest only controls class design to analyze the data. The data were analyzed and interpreted by means of SPSS 23.0 version. The study reveals that the effectiveness of written corrective feedback has a significant effect on students' writing achievement in term of content of the text: content, organization, vocabulary, language use and mechanic. The result of students' writing score from control class and experimental class demonstrated a significant difference. It is found that the experimental class outperformed the control class in writing achievement with $\mathrm{t}=9.021$, $\mathrm{df}=66$ and $\mathrm{P}=.000$ and $95 \%$ Confidence Interval ranging from 9.138 to 14.332 . From the sig. (2-tailed) we can see the $\mathrm{P}$ is lower than $5 \%(0.000<0.005)$. So, it can be concluded that the value is significant in 5\% significant level. Thus, the significance different between the mean value of both class is found.
\end{abstract}

Keywords: effectiveness, written corrective feedback, teaching writing cause effect

\section{INTRODUCTION}

Writing can be very useful for students because it help students to convey their message through their minds in written form. Harmer (2004: 31) states that writing is a way to produce language and express the idea, feeling, and opinion. However, writers are not able to construct a good writing if they do not know the concepts in writing a good written text.

Despite the fact that producing good writing is not easy, there are ways to achieve successful writing. So, it requires students to present ideas into writing, master the writing organization and the importance of linguistic knowledge including grammar and vocabulary. In reality, students find problems when they are given written assignments S. Lee (2005: 335). This condition also happens at the eleventh grade students of SMAN 1 Grogol Kediri. Their problem in compiling written assignments related to grammatical errors, difficulty in producing their own ideas in the form of writing, and students not realizing how to write well using coherence. One way to help students solve their problems is to tell them about their own mistakes. Providing corrective feedback is claimed to be 
an effective way because it allows teachers for providing broad corrective feedback to encourage students realizing their mistakes.

Corrective feedback is information that is given to students about the linguistic errors they have produced. This has been seen as a guide for students to use the target language that is not appropriate. A. Abu Seileek and A. Abualsha'r (2014:76) stated that corrective feedback is one of the most important tools for improving English learning and teaching by providing feedback for students to correct their mistakes. In addition, C. V. Beuningen (2010:27) proposed that corrective feedback is a tool that encourages language learning that helps students to develop their accuracy because it offers a reflection of their linguistic errors. Finally this study defines that corrective feedback is information provided to students regarding linguistic errors. This kind of feedback is used to indicate language errors. Indications of language errors help students to reflect on their mistakes. Student reflections help them build the ability to detect language errors and develop accuracy. Finally, feedback can encourage their language learning.

SLA literature reveals some of the benefits of corrective feedback. The first benefit relates to the accuracy of the grammar of writing. There is a claim that written corrective feedback is an effective learning tool that helps students to write accurately and effectively because it offers grammar notifications that allow them to revise their written work. For example, a study of D. Ahmadi, P. Maftoon, and A. G. Mehrdad (2012:46) revealed that corrective provisions allow students to use participatory phrases and avoid the use of resilient pronouns with far greater accuracy. The second benefit of corrective feedback is related to the organization of ideas. T. K. D Pham (2015:17) proposes that providing written corrective feedback to students helps improve students' ability to organize their ideas in writing composition. The third benefit of corrective feedback is related to the use of accurate lexicons. N. M. Diab (2015:34) states that corrective feedback is an effective tool to help students manage the wrong lexicon. The fourth benefit of corrective feedback is related to student awareness. Some claim that providing corrective feedback makes students aware of their mistakes. One example is E. Ebadi's (2014:884) research which found that written corrective feedback (WCF) helps students realize their own mistakes and monitor themselves. It also shows that when students realize their mistakes, it causes fewer errors in writing because it helps them to correct their mistakes.

In the corrective feedback literature there are six types of corrective feedback. The corrective feedback among them, including direct corrective feedback, indirect corrective feedbacks, metalinguistic corrective feedback, focus on feedback, electronic feedback, and reformulation. Each corrective feedback mentioned above has different characteristics in its application. However, researchers focused on direct feedback that was more beneficial to the SLA, provided it was delivered in a manner that was in line with the intended meaning of the author. The reason given for the effectiveness of this greater direct feedback is that it provides clear and immediate information about the correct version, allowing learners to see more efficient gaps between their current performance and target features (Bitchener and Knoch, 2010, Ferris et al., 2013). In addition, he avoids the possibility of difficulties in deciphering and using codes to modify 
their drafts (Ferris, 2003). Based on the background above, in this research, the researcher would like to find out the answers of the following question.

1. How is the students' writing achievement in teaching writing cause effect which is not taught by using written corrective feedback at the eleventh grade of SMAN 1 Grogol Kediri?

2. How is the students' writing achievement in teaching writing cause effect which is taught by using written corrective feedback at the eleventh grade of SMAN 1 Grogol Kediri?

3. Is there any significant difference of students' achievement in writing cause effect which is taught and not taught by using written corrective feedback at the eleventh grade of SMAN 1 Grogol Kediri?

4. Is written corrective feedback affective to be used to teaching writing cause effect at the eleventh grade of SMAN 1 Grogol Kediri?

\section{METHODS}

The research method used in this research was Posttest-Only Control-Group Design. This research used two classes based on the result of the choice of the teacher who teaches English; they were experimental class and control class. The subjects of this study are the students of SMAN 1 Grogol Kediri from Natural Science program that are XI MIA 4 and XI MIA 5 class in the academic year 2019-2020. The researcher chooses two classes which XI MIA 4 becomes experiment class and XI MIA 5 becomes control class.

The instrument used in this research was writing test and questionnaire. In this research took one of the tests, namely post-test only. The design worked as follows: subjects in experimental class were given 'treatment' whereas subject in control class were not given treatment. Both classes were scored to determine the outcome. The score were gotten from the test administered. The results of the test were used to find out whether or not the treatment applied in experimental class had an effect or a significant difference from control class. Besides the test there is also a questionnaire, which we use as added value to prove the effectiveness of written corrective feedback given to the experimental class and how they respond after getting the written corrective feedback from the treatments given.

The students were asked to choose one of the topics to be written and make a dialogue about cause and effect text based on your own word. Write dialogue minimum use 5 signal words cause and effect which varies. Please, underline signal words that you use in your dialog, the time allocation for doing the test was 60 minutes. Their writing would be scored based on some aspects, those are: content 30, organization 20, vocabulary 20, language use 25, and mechanic 5 . Instrument was tried out to XI MIA 4 and XI MIA 5 with 35 students in each group. Before the instrument were tested to experimental class and control class. It was done to find out the instrument quality, they were; its validity, its reliability, and its normality.

\section{RESEARCH FINDING}

From the result, the researcher find the significant different between students' achievement in writing cause effect in experimental class by using 
written corrective feedback and control class without using written corrective feedback. In this case, the data got from computation of using descriptive statistic that is t-test. In finding t- test, the researcher used SPSS. The result of calculation by using SPSS could be seen as follow in table 4.7 .

Table 4.7 Table of Independent sample T-test

\begin{tabular}{|c|c|c|c|c|c|}
\hline \multicolumn{6}{|c|}{ Group Statistics } \\
\hline & GROUP & $\mathrm{N}$ & Mean & Std. Deviation & Std. Error Mean \\
\hline SCORE & EXPERIMENTAL CLASS & 34 & 82.74 & 5.550 & .952 \\
\hline & CONTROL CLASS & 34 & 71.00 & 5.170 & .887 \\
\hline
\end{tabular}

Table 4.7 reveals a difference in mean value between the experimental class $(\mathrm{M}=82.74, \mathrm{SD}=5.550)$ and the control class $(\mathrm{M}=71, \mathrm{SD}=5.170)$. In order to examine whether the experimental class and control class differed significantly in the test achievement, an independent-samples t-test was conducted using an alpha level of 0.05 . The result is indicated in table 4.8

Table 4.8 Independent-Samples T-test Result

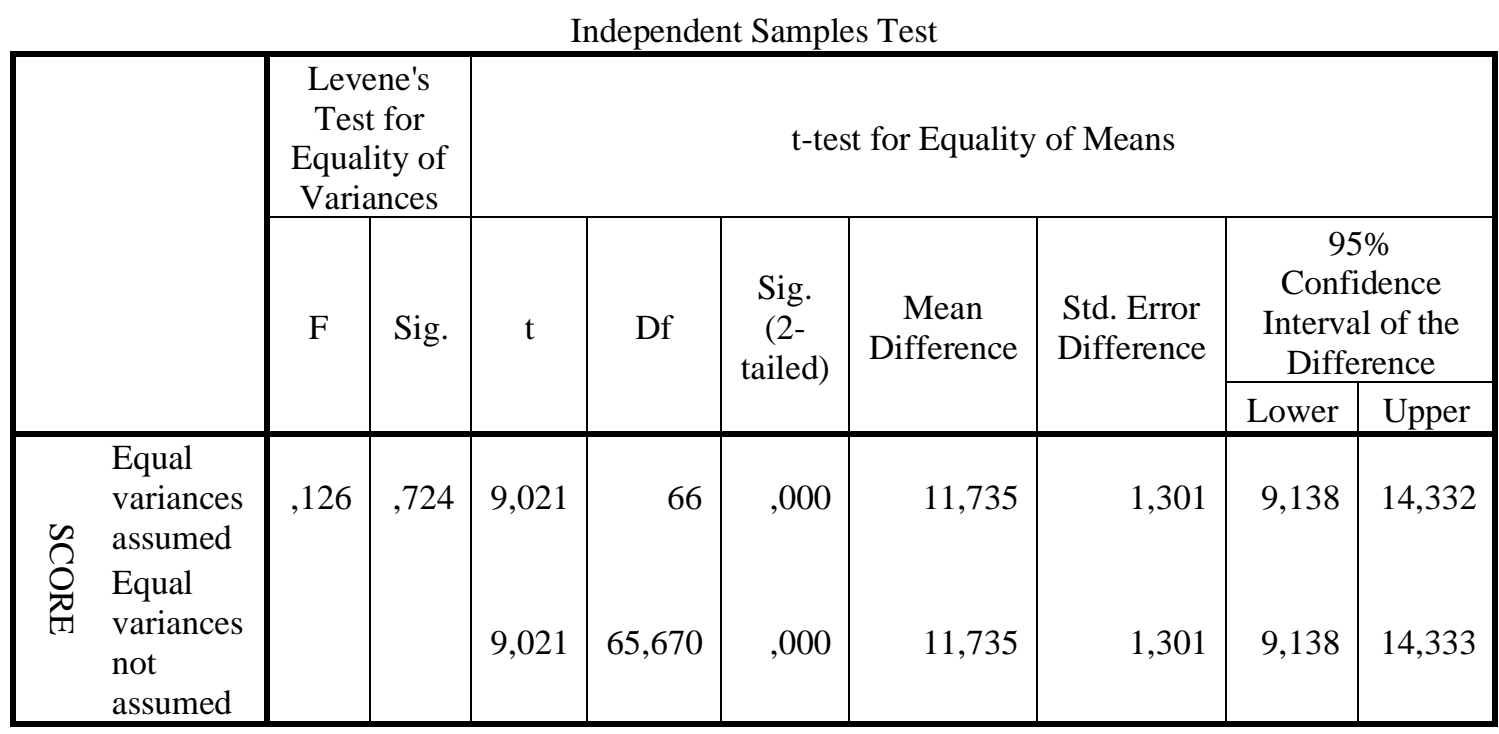

The interpretation of the table above is: there is significant difference between two classes if sig. (2-tailed) values is the same as or lower than $5 \%$ or 0.05 . From table 4.8 , it can be seen that the experimental class outperformed the control class in writing achievement with $\mathrm{t}=9.021, \mathrm{df}=66$ and $\mathrm{P}=.000$ and $95 \%$ Confidence Interval ranging from 9.138 to 14.332. From the sig. (2-tailed) we can see the $\mathrm{P}$ is lower than $5 \%(0.000<0.005)$. So, it can be concluded that the value is significant in $5 \%$ significant level. Thus, the significance different between the mean value of both class is found.

The Alternative hypothesis $\left(\mathrm{H}_{\mathrm{a}}\right)$ states that written corrective feedback is affective to be used teaching writing cause effect at the eleventh grade of SMAN 
1 Grogol Kediri. Before testing this hypothesis, $t$-test is calculated to compare the means between the experimental and control class.

WCF Strategy, which is used as teaching strategy in this research, is effective because the research findings show some indicators, those are; 1) the mean score of experimental class $(\mathrm{M}=82.74)$ is higher than control class $(\mathrm{M}=$ $71)$; 2) the result reveals that experimental class outperforms the control class with significance value $0.0 \%$ or 0.000 as indicated in Table 4.8 , and 3 ) $t$-observed ( $t_{\text {obs }}$ $=9.021)$ is higher than $t$-table $\left(t_{\text {table }}=2.65\right)$. Therefore, the Null Hypothesis is rejected in favor of the Alternative Hypothesis. Thus, Written Corrective Feedback Strategy is effective to be used in teaching writing cause effect text at the eleventh grade of SMAN 1 Grogol Kediri.

\section{DISCUSSION}

Based on the students writing achievement in control class, it was show that the students who got score 85-100 (very good) is 0\% students, the students who got score 69-84 (good) is 18 or 52.94\% students, the students who got score 53-68 (fair) is 16 or $47.05 \%$ students, the students who got score 37-52 (bad) and 20-36 (very bad) is 0 students. It means that students writing skill was good category.

Based on the students writing achievement in experimental class, it was known that 17 students or 50\% got 85-100 in very good category, 17 students or $50 \%$ got 69-84 in good category, 0 students or $0 \%$ got score 53-68 in category fair category, 37-52 in category bad category and 20-36 in category very bad category. It means that the average skill of students' writing in learning English was very good category.

The result obtained that mean of class experiment 82.74 was higher than the mean of class control 71. Meanwhile, their standard error mean values are 0.952 and 0.887. The standard deviation value of both class are 5.550 and 5.170. Furthermore, the mean difference between both classes is 11.735. These result indicated that there were significant differences between teaching writing skill in control class and experimental class was found.

\section{CONCLUSION}

From the result of the research that has been described before, some conclusion are taken as the answer of focus of research in chapter 1 . The conclusions are served below:

1. The students' writing cause effect text achievement in control class without using written corrective feedback strategy at SMAN 1 Grogol Kediri is good and the mean was 71 and had been consulted to the system of category among 69-84. Based on KKM, the students is still low in writing skill.

2. The students' writing cause effect text achievement in experimental class by using written corrective feedback strategy at SMAN 1 Grogol Kediri is very good and the mean was 82.74 and had been consulted to the system of category among 85-100.

3. The result SPSS 23, there is significance difference between teaching writing cause effect text in experimental class by using written corrective feedback strategy and without using written corrective feedback strategy. The score are 
showed that experimental class is higher than control class, level significant $t_{o}$ is 9.021 .

4. Teaching writing cause effect text in experimental class by using written corrective feedback strategy is effective. 1) the mean score of experimental class $(\mathrm{M}=82.74)$ is higher than control class $(\mathrm{M}=71) ; 2)$ the result reveals that experimental class outperforms the control class with significance value $0.0 \%$ or 0.000 as indicated in Table 4.8 , and 3) t-observed (tobs $=9.021$ ) is higher than $\mathrm{t}$-table $\left(\mathrm{t}_{\text {table }}=2.65\right)$.

\section{REFERENCES}

A. Abu Seileek and A. Abualsha'r. 2014. Using peer computer-mediated corrective feedback to support EFL learners' writing. Language Learning \& Technology

C. V. Beuningen. 2010. Corrective feedback in L2 writing: theoretical perspectives, empirical insights, and future directions. International Journal of English Studies.

D. Ahmadi, P. Maftoon, and A. G. Mehrdad, "Investigating the effects of two types of feedback on EFL student's writing," Procedia-Social and Behavioral Sciences, vol. 46, pp. 2590-2595, 2012.

E. Ebadi. 2014. The effect of focused meta-linguistic written corrective feedback on Iranian intermediate EFL learners' essay writing ability. Journal of Language Teaching and Research.

Harmer, 2004. How to Teach Writing. Edinburg: Pearson Education Limited.

Heaton, J.B. 1989. Writing English Language Teaching. London: Longman Group Ltd.

J. Bitchener and U. Knoch. (2008:409). "The value of written corrective feedback for migrant and international students" Language Teaching Research

N. M. Diab. 2015. Effectiveness of written corrective feedback: does type of error and type of correction matter? Assessing Writing.

S. Lee. (2005:335). "Facilitating and inhibiting factors in English as a foreign language writing performance: A model testing with structural equation," Journal of Language Learning 